LSP International Journal, Vol. 7, Issue 1, 2020, 1-26

(C) Universiti Teknologi Malaysia

E-ISSN 2601-002X

DOI: https://doi.org/10.11113/lspi.v7n1.93

\title{
Cognitive Reading Strategies Employed by Form Three Malaysian English as Second Language (ESL) Students
}

\author{
Jessica Abisheganathan Jeevaratnam \& Mahani Stapa \\ Language Academy, Faculty of Social Sciences and Humanities, Universiti Teknologi Malaysia, 81310 UTM \\ Johor Bahru, Johor, Malaysia
}

Submitted: 2/02/2020. Revised edition: 18/03/2020. Accepted: 30/05/2020. Published online: 30/06/2020

\begin{abstract}
Previous studies reported that many low proficiency students have poor comprehension skills. Therefore, this research aims to study the cognitive reading strategies employed by ESL (English as Second Language) students and suggest appropriate cognitive strategies to be utilized by low proficiency students. This research was carried out in one of the secondary schools in Pasir Gudang, Johor. The purposive sample for this study consists of 60 Form 3 students (30 low proficiency and 30 high proficiency). Explanatory sequential mixed method design was used to carry out this research. The data collected via questionnaire, observation and interview for this research is analysed quantitatively and qualitatively. Descriptive analysis was used to analyse data gained from questionnaire and observation whereas for the interview data, extracts from the interviews were used to corroborate the findings. The findings reveal that the most common cognitive reading strategies employed by both group of students are skimming and translation. This research further highlights the most significant difference in reading strategies between both groups of students, which is, the high proficiency group outperformed the low proficiency group in overall strategy use, demonstrating the most frequent use of the strategies. Most prominently, in this research, the reading strategies that are deemed appropriate for the low proficiency students are highlighted. These strategies include four cognitive strategies; guessing, elaboration, summarizing and prediction.
\end{abstract}

Keywords: Cognitive reading strategies, ESL students, secondary school, explanatory sequential mixed method design, purposive sample

\subsection{INTRODUCTION}

Reading is an art that calls for skills to be mastered with the purpose of understanding the text (Halim \&Mohamed, 2006). It is believed that students can read from page one to the last page, but without proper reading skills, students will not understand or recall what they have read. They usually consider reading as recognizing words. A few even think that after reading all the words orally, they have understood the text. Besides that, these students often focus on remembering small details rather than constructing their own meaning (Richek et al., 2002).

*Correspondence to: Mahani Stapa (email: mahani@utm.my) 
In other words, they are less able to distinguish between essential and non - essential details from the text.

Previous researchers also added that one of the factors influencing reading proficiency is cognitive reading strategies (Prichard, 2014). Cognitive strategies help in constructing meaning from the text. These strategies are categorised into bottom-up and top-down. It is believed that all the students should be exposed to these strategies so that they can utilize these strategies efficiently.

However, Mohamed et al. (2006) stated that activities carried out in the classroom do not all the time enable students to use strategies and skills to infer, predict, agree, analyse, evaluate and criticize by interrelating with the given reading comprehension text. In relation to this, Raj (2008) stated that Durkin (1979) in his classic observational study of reading comprehension instruction noticed that only 20 out of 4469 minutes were used by the teachers on comprehension instruction. It is evident that the teachers use mostly all of the instructional time questioning students and use less time teaching students comprehension strategies they could employ while answering questions. Based on the background of the research, the aim of this research is to find out the cognitive reading strategies used by high and low proficiency students and highlight the significant differences in the strategies used by students from both groups.

\subsection{RESEARCH OBJECTIVES}

i) To find out the cognitive reading strategies employed by the Form Three low proficiency students

ii) To identify the cognitive reading strategies employed by the Form Three high proficiency students

iii) To find out the significant differences in cognitive reading strategies employed by the Form Three low and high proficiency students

\subsection{LITERATURE REVIEW}

This section will provide an overview of second language reading comprehension. It will also highlight the ESL reading strategies, more specifically cognitive reading strategies. Furthermore, this section will also bring to light the importance of teaching cognitive reading strategies.

\section{A. Second Language Reading Comprehension}

Previous researches brought to light that reading has a purpose. Its purpose is "to construct text meaning based on visually encoded information" (Koda, 2007). The difference between first language and second language reading is that, the latter requires students to use minimum two languages 
whereas the former deals only with one language. Due to this, second language students face more difficulties compared to first language students. Therefore, it is believed that with the aid of reading strategies, second language readers might overcome the challenge and improve their level of comprehension.

In addition, Carrell and Grabe (2002), further discussed the reasons why L2 students apply reading processes which are different from the $\mathrm{Ll}$ students. The causes are as follow:

i. lack of linguistic knowledge among L2 students;

ii. lack of cultural and social knowledge among L2 students

iii. poor retention of background knowledge

iv. usage of first language and second language

(Carrell \& Grabe, 2002, p.2)

All these reasons show that ESL students face difficulties in developing their comprehension skills. Thus, teachers should provide explicit instruction on cognitive reading strategies and allow the students to practice utilizing these strategies. When they practice utilizing these strategies, they will be aware of the strategies that are appropriate for them. These appropriate strategies can be employed by them to comprehend the reading comprehension texts that they encounter during examinations.

Kucukoglu (2013) agreed that without a firm and solid foundation of reading comprehension strategies, students will face difficulties throughout their academic and adult life. In short, students who are not exposed to reading comprehension strategies, lack the critical thinking skills that are essential in this 21 st century. Therefore, it is believed that to enhance the quality of second language comprehension, teachers should teach the appropriate reading comprehension strategies to all students (low and high proficieny students). In relation to this, this research presents the cognitive reading strategies employed by high and low proficiency students and significant differences of reading strategies between both the groups.

\section{B. Reading Strategies}

The four factors connected to reading comprehension are the reader, the text, the strategies, and the goal (King, 2008). However, it is emphasized that reading strategies is the factor that creates differences between students. Students who have the knowledge on using these strategies will use these strategies when reading. Reading strategies is defined as "the mental operations involved when readers approach a text effectively to make sense of what they read... Good readers apply more strategies more frequently ... and more effectively than poor readers" (Pani, 2004). It can be inferred that low proficiency students are not exposed and not alert of the importance of utilizing reading strategies.

Furthermore, Karami (2008) provided a concrete description of reading strategies. He described strategies in reading as the "conscious, internally variable psychological techniques... aimed at improving the effectiveness of or compensating for the breakdowns in reading comprehension...on 
specific reading tasks and in specific contexts". Based on this definition, three key points regarding reading strategies can be derived. The three key points are as below:

1. Reading strategies are devices that can be used to comprehend texts

2. Reading strategies are employed according to the content of the text and task

3. Reading strategies aim to improve students' academic performance in reading comprehension

(Karami, 2008, pp. 2-3)

In relation to this, teachers play an essential role to improve students' reading skills through instruction of reading strategies. Teachers need to provide clear, detailed instruction over a long period of time, instructing students in the cognitive processes and strategies that proficient readers use most often. Explicit instruction includes showing students not only what to do, but when, why, and how to do it. In short, as students practice these new strategies, the teacher models or leads them through the steps until they can independently perform them on their own. Based on Vacca and Vacca's (1999) understanding of role of teachers, the following steps are proposed to be employed by teachers:

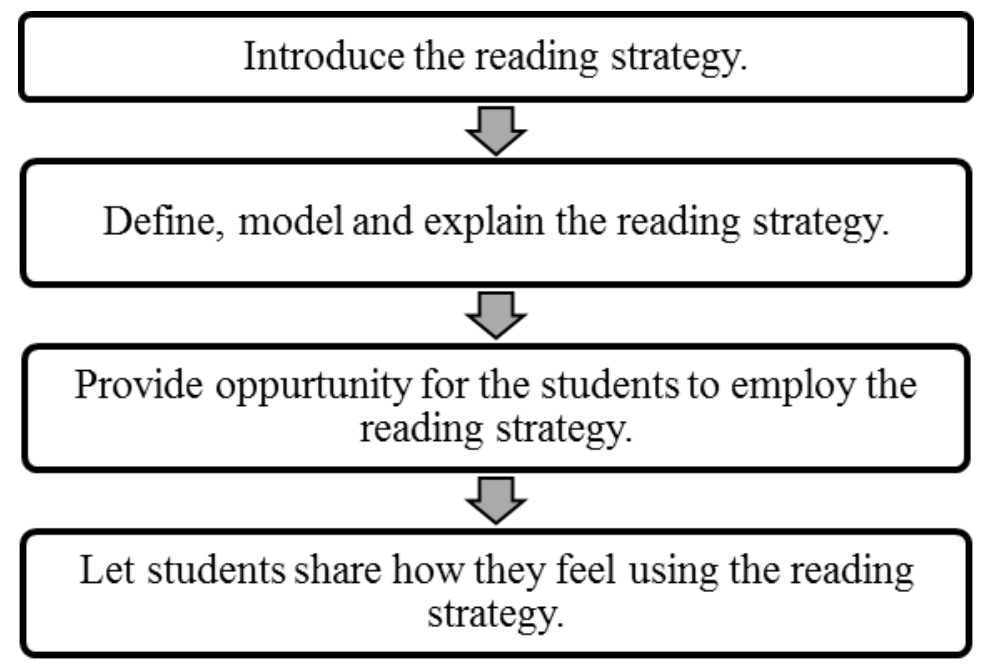

Figure 1.0 Steps to teach reading strategies

Most prominently, Julius (2015) recommended that teachers need to be more dexterous and resourceful in their teaching of reading comprehension strategies. This is because teachers should be well-equipped first before guiding their students to become proficient readers. Besides that, teachers should observe and gain knowledge about students' interests, abilities and skills. All these enable the teachers to adjust their instruction. They should ensure that all students (low and high proficiency) 
are exposed to reading strategies. If students face difficulties in employing the reading strategies that are introduced, teachers should modify their practice accordingly.

\section{ESL Reading Strategies}

Semtin and Maniam (2015) claimed that ESL reading comprehension strategies assist students through the stages in reading and guide them to understand the content of the text. Therefore, it is essential to introduce the reading comprehension strategies through examples. Teachers should discuss how, when, where, and why the strategy are used. Moreover, Nordin et al. (2013) agreed that students that are equipped with ESL reading comprehension strategies may be more successful than others. They will be more proficient readers, as these strategies aid them to read accurately and follow the text more closely. Aziz et al. (2011) also added that these strategies give students an idea of the content and message in the text. All these clearly indicate that without ESL reading strategies, students will face challenges in comprehending the reading comprehension texts.

Previous studies highlighted that there are different types of reading comprehension strategies. To serve the purpose of this research, the focus has been narrowed down to only on cognitive reading comprehension strategies which is one of the categories proposed by O'Malley and Chamot (1990); cognitive, metacognitive and social-affective.

\section{Cognitive Reading Strategies}

The most well-known strategies among students is cognitive reading strategies (Oxford, 1990). Students need to be equipped with suitable ways of instruction to use this strategy as effectively as possible. Furthermore, there are several researches that highlight the value of cognitive strategies. First, there are notable researches that compare high proficiency students with low proficiency students (Chan et al., 1992; Chi et al., 1989). It is evident that there are significant differences in strategy use between high and low proficiency students. Next, there are researches that experimentally examine the consequences of teaching students to use reading comprehension strategies (Graham et al., 1995). These studies proved that who learn the new strategies managed to tackle the reading comprehension texts better than the low proficiency students.

Furthermore, there are also researches that come from long-term classroom experiments or quasi-experiments (Brown et al., 1996; Guthrie et al., 2004). The duration to carry out these studies took many months. The aim of these studies is to compare and contrast classroom practice that focus on strategy instruction. The finding from these studies proved that students who are exposed to steps of employing reading strategies managed to enhance their reading comprehension skills.

As a whole, it can be inferred that different reading comprehension tasks requires different reading strategies. Teachers should scrutinize strategies that have proven to be effective in reading comprehension and introduce them to the students. 


\section{E. Importance of Teaching Cognitive Reading Strategies}

In the reading comprehension domain, there is plentiful of evidence that shows reading strategies improve reading comprehension. Therefore, strategy instruction is particularly necessary for students, especially for low proficiency students. It is believed that there are two important reasons why teachers should provide clear instruction on the usage of cognitive reading strategies.

The first reason is to develop students' understanding towards the reading comprehension text. Previous studies highlighted that cognitive reading comprehension strategies are important in constructing students' understanding of texts (Nietfeld \& Shraw, 2002). As students become more expert at using these strategies, they will be more confident and more independent as learners. They will be able to utilize these strategies to comprehend the reading comprehension texts that they encounter during examinations.

The second reason is to encourage students to become strategic readers. Brown and Briggs (1989) proposed four characteristics of strategic readers. The characteristics are as below:

i. Establish aims for reading.

ii. Determine reading strategies appropriate for the text.

iii. Keep track of their reading

iv. Set a positive attitude towards reading.

Based on these characteristics, it is believed that students might become strategic readers if they employ cognitive reading strategies. Thus, it is crucial to expose students to a number of types of cognitive reading strategies.

As a whole, teaching cognitive strategies to students at different levels of proficiency is important. Teachers should understand the content of the text beforehand and equip themselves with extensive knowledge of these strategies. They should be aware of the strategies that are appropriate for different groups of students and types of content. Above all, they must know how to teach and model strategy use.

\subsection{METHODOLOGY}

Explanatory sequential mixed method design is selected to carry out this research. The purposive sample for this study consists of 60 Form Three students (30 low proficiency and 30 high proficiency) in one of the secondary schools in Pasir Gudang, Johor. They were all aged fifteen and are of mixed races; Malays, Chinese and Indians. These students were categorized as low and high proficiency based on their previous year's final year examination score. Students who scored $40-49$ were categorized as low proficiency whereas students who scored 75 and above is categorized as high proficiency. 


\section{A. Research Instruments}

Three types of instrument to collect data includes questionnaire, observation checklist, and interview protocol.

\section{Questionnaire}

The researcher prepared a questionnaire by adapting a questionnaire derived from a research on reading strategies carried out by Semtin and Maniam (2015). It consists of Likert Scale statements. Respondents were required to read each statements and express their agreement on each statement. The type of questions in this questionnaire is closed questions. The data gained from this closed question can be interpreted, tabulated and summarized the data easily. The significant differences between the reading comprehension strategies used by the high and low proficiency respondents were also highlighted.

\section{Observation Checklist}

The role of an observer is adopted by the researcher. The researcher participated in the in-class reading task and recorded information using an observation checklist. Furthermore, the lesson is recorded in order to replay and study each student's response towards the text given. The main objective of this observation is to observe what are the reading strategies employed by the respondents.

\section{Interview Protocol}

To triangulate the data gathered from the observation and questionnaire, one-on-one interviews were conducted with six respondents respectively (3 low proficiency and 3 high proficiency students). This interview was semi-structured. It allowed the researcher to be flexible to follow the conversation of the interviewee. Open-ended questions were asked and answers were recorded from only one respondent in the study at a time. This type of questions encouraged the respondents to express their thoughts freely. Probes were used to obtain additional information. This interview was recorded in two ways; digital recording and note taking.

\section{B. Data Analysis}

The researcher elaborated the methods to analyse the data based on three types of instrument for data collection which are questionnaire, observation checklist and interview protocol. 


\section{Questionnaire}

The statistical procedure that was used in this research was frequency count. The researcher recorded all the data gathered in SPSS and calculated the frequency. Then, the data gathered was categorized and analysed based on the types of cognitive reading strategies.

\section{Observation Checklist}

The content from observation data was analysed based on researcher's field notes. The researcher provided a descriptive account of the data gathered from the observation. This descriptive account triangulated the data obtained from questionnaire.

\section{Interview Protocol}

The interview data was analysed based on narrative analysis. The researcher transcribed the interview, presented the extracts and reflected upon them. Similar to observation data, these extracts were used to triangulate the data gathered from the questionnaire. To conclude, the methods of data analysis is presented in the following table:

Table 1.0 Summary of data analysis

\begin{tabular}{|l|l|}
\hline \multicolumn{1}{|c|}{ Research Instrument } & \multicolumn{1}{|c|}{ Methods Of Data Analysis } \\
\hline \multirow{2}{*}{ Questionnaire } & Descriptive Analysis - Frequency count \\
\cline { 2 - 2 } & Thematic Analysis \\
\hline Observation & Content Analysis \\
\hline Interview & $\begin{array}{l}\text { Narrative Analysis - triangulated the data obtained from } \\
\text { questionnaire and observation }\end{array}$ \\
\hline
\end{tabular}

\subsection{RESULTS}

The most common cognitive strategy employed by the low proficiency students are skimming, repetition and translation whereas the least common cognitive strategy employed by them are guessing, prediction, analyzing, inferring, summarizing and elaboration. On the contrary, the high proficiency students employ all ten cognitive reading strategies. The data gathered has been grouped according to types of cognitive strategies and is presented in the following sub-sections. 


\section{A. Types of Cognitive Strategies}

\section{Skimming}

Richards et al. (1992) see skimming as reading for gist, a type of rapid reading which is used when the reader wants to quickly identify the main ideas from a passage. Findings from the questionnaire show that $63 \%$ of the low proficiency respondents agree and $37 \%$ of them strongly agree that they skim the text quickly to have a general understanding of the text. Therefore, it is clearly evident that all the low proficiency respondents employ this strategy. On the other hand, 70\% of the high proficiency respondents agree and $30 \%$ of them strongly agree that they employ this strategy. This shows that all the high proficiency respondents also employ this strategy.

Furthermore, the findings from the interview also reveal that these respondents employ skimming strategy. Below are the findings from all the six interviewees regarding the usage of skimming strategy:

\section{$\underline{\text { Low proficiency }}$}

Respondent $X 1$ - ...I read the title of the text and look at the picture given...

Respondent $X 2$ - ...I read the paragraph one and last paragraph...

Respondent $X 3$ - ...I read the title and all the words in dark colour (boldface words)...

\section{High proficiency}

Respondent $\mathrm{Y} 1$ - ...Usually I read the first sentence in each paragraph to know what is the text about...

Respondent $\mathrm{Y} 2$ - ...I glance through the text in order to know the overall content of the text...

Respondent $\mathrm{Y} 3$ - ...I will try to detect the main idea in the first paragraph because usually in the introductory paragraph the overall idea of the text will be emphasized...

These findings clearly indicate that both low and high proficiency respondents employ skimming strategy in order to get an overall impression of the content of the text. In addition, it is also evident in the observation that all the respondents (low and high proficiency) skim through the given reading comprehension text. Therefore, it is clear that skimming is one of the cognitive strategies that are popular among the respondents. Brown (1994) highlights that for efficient comprehension, skimming strategy is the most valuable for learners. It requires an overall view of the text and implies a definite reading competence.

\section{Prediction}

The questionnaire findings for the second cognitive strategy, which is prediction, show that $50 \%$ of the low proficiency respondents strongly disagree and $47 \%$ disagree that they employ the prediction strategy. This clearly shows that $97 \%$ of the low proficiency respondents do not predict the content of 
the upcoming passage or section while reading. On the other hand, $14 \%$ of the high proficiency respondents agree and $73 \%$ strongly agree that they employ prediction strategy. Thus, showing that majority of the high proficiency students employ this strategy.

It is also evident in the interview findings that low proficiency students do not employ the prediction strategy as oppose to high proficiency students. Following are the findings from the interview:

\section{Low proficiency}

Respondent $X 1$ - ...I do not guess the content of the text...

Respondent $X 2$ - ...I do not guess the main idea of the text...

Respondent X3 - ...Saya tak cuba untuk guess apa kandungan teks...

(I did not try to guess the content of the text)

\section{High proficiency}

Respondent $Y 1$ - ...I predict the main idea in the text ...

Respondent $Y 2$ - ...I guess the content of the text as I read the text...

Respondent Y3 - ...I make assumptions of the content...

From all these findings, it can be inferred that high proficiency students guess the main idea of the text as they read it unlike the low proficiency students. The researcher believes that predicting helps high proficiency students become actively involved in reading and helps to keep their interest level high. This is because making predictions activates students' prior knowledge about the text and helps them make connections between new information and what they already know. By making predictions about the text before, during, and after reading, students use what they already know, as well as the content of the text, to make connections to the text. In short, through prediction strategy, students can read through the text and refine, revise, and verify their predictions.

During the observation, the researcher noticed that the high proficiency students were highly motivated to connect the text with the graphic assisted and make assumptions with their friends about the content of the text. On the contrary, the low proficiency students were quite passive and just focussed merely on reading the text. They were not seen discussing with their friends about the information in the text. According to Duke and Pearson (2002), prediction is a prominent strategy that can improve comprehension. This is because students will be able to use information from graphics, text and experiences to anticipate what will be read and to actively adjust comprehension while reading.

\section{Analysing}

The questionnaire findings for the third type of cognitive strategy, analyzing, show that $80 \%$ of the low proficiency respondents disagree and $17 \%$ strongly disagree that they analyse the relationships between the given reading text and reading tasks. On the contrary, 23\% of the high proficiency 
respondents strongly agree and $37 \%$ agree that they find the connection of the reading text and the task given. This implies that majority of the high proficiency students employ analysing strategy.

Additionally, during the interview, the high proficiency students shared the reasons they make connections of the reading text and task given. The responses elicited from the interviewees are as follow:

Low proficiency

Respondent $X 1-\ldots \mathrm{I}$ do not find any connection...

Respondent $X 2-\ldots I$ do not know any relationship of the text with the questions...

Respondent $X 3$ - ... am not sure what is connection antara text and questions... (I am not sure what is the connection between the text and questions)

High proficiency

Respondent $Y 1$ - ...I find connection between the text and task given...

Respondent Y2 - ...I make connections because I read with a reason, which is, to answer the questions given. Therefore, if I make connections between the text and task, I will be able to complete the task successfully and determine why I am reading the text given...

Respondent $\mathrm{Y} 3$ - ...I relate the text and tasks in order to understand the text better...

As a whole, from these findings, the researcher believes that analysing strategy requires students to set a purpose. Row and Smith (2005) stated that students who read with a purpose tend to comprehend what they read better than those who have no purpose. This may due to the fact that the students are attending to the text rather than just decoding words.

Purpose-setting activities such as think-aloud and group investigations can help students activate their existing background knowledge about the topic of the material. Besides that, providing specific purposes avoids presenting students with the insurmountable task of remembering everything they read and allows them to know whether they are reading to determine main ideas, locate details, understand vocabulary terms, or meet some other well-defined goals. As a result, they can apply themselves to a specific, manageable task.

Furthermore, Stuck (2000) suggested that for maximum effectiveness, setting a single purpose for reading, especially for low proficiency students, helps avoid confusion from the overload of multiple purposes. The purpose should be fairly broad in scope and sustained throughout the entire selection, not met after reading only a small portion of the materials. Purposes should be formed carefully, because poor ones can misdirect the students' attention by focusing on information that is not essential to the passage. Most importantly, purposes should help these students differentiate between relevant and irrelevant information. Responsibility for setting purposes should gradually shift from the teacher to the students. 


\section{Inferring}

The questionnaire findings for the fourth cognitive strategy, inferring, show that only $3 \%$ of the low proficiency respondents agree that they employ the inferring strategy whereas $40 \%$ of the high proficiency respondents agree and $13 \%$ strongly agree that they attempt to understand the underlying meaning of the given text. This shows that high proficiency students are able to make a logical guess and read between the lines. The result is that they create new meaning or draw a conclusion that is not explicitly stated in the reading (Zweirs, 2005).

Additionally, the interview findings also reveal that the low proficiency students do not employ the inferring strategy whereas the high proficiency students employ this strategy. Below are the findings from the interview:

\section{Low proficiency}

Respondent $X 1$ - ...I do not know what is inferring...

Respondent $X 2-\ldots \mathrm{I}$ am not sure what is inferring ...

Respondent $X 3$ - ...I tak pernah infer..infer... (I have never inferred)

\section{High proficiency}

Respondent $Y 1$ - ...I make reasonable guesses in order to understand the text...

Respondent $\mathrm{Y} 2$ - ...I like to look for the underlying meaning of the text ...

Respondent $\mathrm{Y} 3$ - ...I am aware that each text has an underlying meaning. So, its important for me to understand the underlying meaning before answering the questions given...

As a whole, the researcher believes that inferring strategy is not widely employed by the low proficiency students because inferring requires higher order thinking skills. Inferring is a "foundational skill" - a prerequisite for higher-order thinking and 21st century skills (Marzano, 2010). This strategy can be taught through explicit instruction. In Malaysian ESL classrooms, this skill is used across the curriculum, including English language arts, science and social studies.

It is believed that if students use no other resources than their own background knowledge to create meaning, their comprehension of the text is limited. On the other hand, using only text disallows the validity of their personal point of view, no connection is made, and only literal comprehension may result. Therefore, when students infer, they are personally engaged with the text, are more aware of the author's purpose, and are processing the content to deeper meaning (Zweirs, 2005).

\section{Translation}

Findings from the questionnaire indicate that $77 \%$ of the low proficiency students agree and $16 \%$ of them strongly agree that they do translate what they have read into their first language, which is Bahasa Melayu. Moreover, $63 \%$ high proficiency respondents strongly agree and $37 \%$ agree that they 
employ the translation strategy. This clearly shows that translation strategy is employed actively by most of the low and high proficiency students. Furthermore, all the six interviewees stated that they translate the text into their first language to comprehend the text better. Following are the findings from the interview:

\section{Low proficiency}

Respondent $X 1$ - ...I translate the text to BM...

Respondent $X 2-\ldots I$ write the translations on the text...

Respondent X3 - ...saya translate dalam Bahasa Melayu...

(I translate the text to BM)

High proficiency

Respondent $Y 1$ - ...I translate the text but only the key points...

Respondent $Y 2$ - ...I translate the text in order to understand the content of the text...

Respondent Y3- ...If I translate the text, it is easier for me to understand the content of the text...

These findings indicate that, in order to understand the text better, both low and high proficiency respondents employ translation strategy. Furthermore, during the observation, the researcher noticed that most of the respondents wrote the translation of the text in pencil on the empty space in the text. Most of the words translated by the respondents are content words. Some examples of content words translated by them are as below:

i. $\quad$ appointed $=$ dilantik

ii. $\quad$ ceaselessly $=$ tanpa berhenti

iii. rural = luar bandar

iv. renowned $=$ terkenal

v. unity = perpaduan

Previous studies reveal that translation plays a positive role in EFL classes. Translation strategy is considered a base for language learners' comprehension and production of the target language. Moreover, students use it as a helping strategy in order to learn and improve the learning of a new language. Moreover, Liao (2006) reported that students mostly used their mother tongue to expand their English knowledge of vocabulary, structures, expressions, and to improve three language skills of reading, writing, and speaking. As a whole, it can be implied that translation strategy can help the learners to check their comprehension of different reading texts and tasks.

\section{Summarising}

The questionnaire findings for the next cognitive strategy, summarizing, reveal that $34 \%$ of the low proficiency respondents disagree and $63 \%$ strongly disagree that they summarise the important 
information and main ideas of the text whereas $83 \%$ of the high proficiency students agree and $10 \%$ strongly agree that they employ summarizing strategy. This clearly shows that majority of high proficiency students employ summarizing strategy.

This is also proved in the interview, in which the high proficiency interviewees claimed that they highlight the main ideas in the text and summarise them. Following are the findings from the interview:

\section{Low proficiency}

Respondent $X 1$ - ...I do not know how to summarise...

Respondent $X 2$ - ...I do not know how to summarise main points...

Respondent X3 - ...saya tak reti nak cari main point... ( $\mathrm{I}$ do not know how to identify the main points)

\section{High proficiency}

Respondent $Y 1$ - ...I underline all the main ideas and summarise the main ideas...

Respondent $\mathrm{Y} 2$ - ...I highlight the main ideas and combine the ideas in my own words...

Respondent Y3 - ...I summarise main points to understand the content of the text. I will also ignore all the examples...

Moreover, in the observation, the researcher noticed that most of the high proficiency students underline the main ideas in the text given to help them understand the text better. Previous research suggested that the usage of summarising strategy not only improves students' ability to summarise text, but also their overall comprehension of text content (Duke \& Pearson, 2002). It is one of the most difficult strategies for students to master and one of the hardest to teach. Effective teaching of summarising requires multiple modeling sessions and many opportunities to practice. However, it is worth persisting with, as it is an extremely useful strategy for students to master as they go on to study at higher levels (Cameron, 2009).

\section{Elaboration}

Gunning (1996) refers to elaboration strategy as an additional processing of the text, by the reader, which may increase comprehension. It involves forming connections between the text and the reader's background knowledge of the subject. The questionnaire findings for this strategy prove that $54 \%$ of the low proficiency respondents disagree and $43 \%$ strongly disagree that they relate their prior knowledge to new information so as to understand the given reading text. On the other hand, $74 \%$ of the high proficiency respondents agree and $23 \%$ strongly agree that they employ elaboration strategy. This implies that the majority of the high proficiency students employ this strategy compared to low proficiency students.

In addition, in the interview, all the high proficiency interviewees stated that they tap on their background knowledge and make connections between their previous knowledge with the new input 
gained from the current reading comprehension text. The responses elicited from the interviewees are as follow:

Low proficiency

Respondent $X 1$ - ...I do not know how to relate background knowledge...

Respondent $X 2$ - ...I do not know what is elaboration strategy...

Respondent $X 3$ - ...I do not make connection antara teks and question...

(I do not make connection between the text and question)

High proficiency

Respondent $Y 1$ - ...I relate what I know earlier with the content of the text...

Respondent Y2 - ...I make connections between my background knowledge and the current reading comprehension text. This allows me to understand the text better...

Respondent Y3- ... correlate the new information from the text and my background knowledge...

All these findings show that low proficiency students do not tap on their background knowledge because they do not know how to do so. They do not realise that by employing the elaboration strategy, they are able to increase their comprehension, as the reading material becomes relevant and meaningful. Since the low proficiency students are not aware of previous knowledge, teachers should encourage schema building by helping students build background knowledge, access the background knowledge, and use it to bridge new learning (Rea \& Mercuri, 2006). If low proficiency students are aware of the elaboration strategy, they will be able to employ it and increase their understanding towards the reading comprehension text.

\section{Repetition}

The findings from the questionnaire reveal that $83 \%$ of the low proficiency respondents strongly agree and $17 \%$ agree that they employ the repetition strategy. On the other hand, $67 \%$ of the high proficiency respondents strongly agree and $30 \%$ agree that they employ this strategy too. Thus, this shows that both low and high proficiency students employ the repetition strategy.

Moreover, during the interview, all the respondents claimed that they employ this strategy. Below are the findings from the interview:

\section{Low proficiency}

Respondent $X 1$ - ...I read many many times before answer the questions...

Respondent $X 2$ - ...When I read many times, I understand the text...

Respondent $X 3$ - ...I always read the text again and again... 


\section{High proficiency}

Respondent $Y 1$ - ...I realise that when I reread, I am more aware of the main ideas in the text...

Respondent $Y 2$ - ...I understand the text better when I reread...

Respondent Y3 - ...If I read for more than 3 times, it will be easier for me to understand the text and answer the questions given...

The findings from questionnaire and interview are also in line with the observation findings where all the low proficiency respondents and 29 out of 30 high proficiency respondents reread the text at least three times to answer the questions given. When students employ this strategy, words that they may have struggled to decode on a first reading become increasingly easier to parse. It is also believed that rereading helps students develop a deeper understanding of what they have read (Roskos \& Newman, 2014, cited by Walsh, 2014). They will be able to read with greater accuracy and fluency, allowing them to give more attention to making sense of what they have read.

\section{Guessing}

The findings from the questionnaire reveal that $83 \%$ of the low proficiency respondents disagree that they employ the guessing strategy. On the contrary, $97 \%$ of the high proficiency respondents strongly agree and agree that they guess the meaning of unknown words or phrases according to the contextual clues. This shows that most of the low proficiency students do not employ guessing strategy whereas majority of the high proficiency students employ this strategy.

Besides that, during the interview, the low and high proficiency interviewees pointed out what they will do if they encounter difficult words. Following are the responses of the interviewees:

Low proficiency

Respondent $X 1-\ldots I$ will check the dictionary ...

Respondent $X 2$ - ...If I do not know the meaning of words, I will check in the dictionary...

Respondent $X 3$ - ...I quickly will check the dictionary...

\section{High proficiency}

Respondent $Y 1$ - ..I will guess the meaning of the words that $I$ do not know based on the whole sentence...

Respondent Y2 - ..I refer the overall context in order to understand unfamiliar words...

Respondent Y3 - ...I guess the meaning of difficult words by referring the words and phrases that are closely associated... 
It is also evident during the observation that the low proficiency respondents were busy looking for meanings in the dictionary. On the other hand, the high proficiency respondents were more keen on guessing the meaning of unfamiliar words. They are not dependent on the dictionary.

All these show that low proficiency students prefer to look for meanings of unfamiliar words in the dictionary whereas the high proficiency students will guess the meaning of these words or phrases by looking at the contextual clues. They personally feel that contextual clues aid them to comprehend the unfamiliar words or phrases. This is in accordance with the findings in a research conducted by Askari (2013). His research findings revealed that guessing strategy has positive effects on students' reading comprehension. Furthermore, Kojima and Narita (2004) reported in their research that guessing strategy has some beneficial effects on student's reading ability and enhanced their word guessing ability significantly. All these findings suggest that students should adapt guessing strategy in order to improve their level of understanding.

\section{Note-taking}

The questionnaire findings gathered for this strategy show that $70 \%$ of low proficiency respondents agree and $20 \%$ strongly agree that they take notes when reading to help them memorise useful information and $57 \%$ of the high proficiency respondents also agree that they employ this strategy. This indicates that this strategy is significantly utilised by the low proficiency students.

Furthermore, the interview findings also show that both low and high proficiency students agree that they employ the note-taking strategy. Below are the interview findings:

\section{Low proficiency}

Respondent $X 1$ - ...I write notes when I read ...

Respondent $X 2$ - ...I take notes when reading the text...

Respondent $X 3$ - ...I write notes beside the text...

\section{High proficiency}

Respondent Y1 - ...I make short notes based on the text...

Respondent $Y 2$ - ...I note down main ideas in the text...

Respondent $Y 3$ - ...I write short notes when I read the text...

In addition, during the observation, the researcher noticed that 27 out of 30 low proficiency respondents wrote short notes based on the text and 17 out 30 high proficiency respondents also did the same. This clearly shows that most of the respondents in this research jot down essential information from the text.

Previous researchers found that if important information was contained in notes, it had a $34 \%$ chance of being remembered. Information not found in notes had only $5 \%$ chance of being remembered (Longman \& Atkinson, 1999). In addition, Austin Community College (2000) listed four benefits of employing note-taking strategy. Following are the benefits of this strategy: 
i. Keeps students alert

ii. Engages students' mind actively with the text that they encounter

iii. Emphasizes and organizes information from the text

iv. Creates a condensed record for students to answer the reading comprehension questions

\section{B. Significant Differences of Reading Strategies Employed by Low and High Proficiency Respondents}

The following table provides an overview of the cognitive reading strategies used by high and low proficiency students and the comparison of strategies employed by them:

Table 2.0 Types of cognitive strategies employed

\begin{tabular}{|l|c|c|}
\hline \multicolumn{1}{|c|}{$\begin{array}{c}\text { Types Of Cognitive } \\
\text { Strategies }\end{array}$} & Low Proficiency & High Proficiency \\
\hline Skimming & $100 \%$ & $100 \%$ \\
\hline Prediction & $3 \%$ & $87 \%$ \\
\hline Analysing & $3 \%$ & $60 \%$ \\
\hline Inferring & $3 \%$ & $53 \%$ \\
\hline Translation & $93 \%$ & $100 \%$ \\
\hline Summarizing & $3 \%$ & $93 \%$ \\
\hline Elaboration & $3 \%$ & $97 \%$ \\
\hline Repetition & $100 \%$ & $97 \%$ \\
\hline Guessing & $17 \%$ & $97 \%$ \\
\hline Note-taking & $90 \%$ & $57 \%$ \\
\hline
\end{tabular}

As a whole, it can be seen that both group of students equally agree that they employ skimming strategy. Skimming is used to rapidly detect the central ideas of a passage. The speed of skimming is about three to four times faster compared to usual reading.

Furthermore, translation strategy is employed by all the high proficiency respondents and majority of low proficiency respondents. Liao (2006) conducted a research to explore EFL students' belief about the use translation strategy. The findings from his study suggested that translation strategy aids students to understand and remember the content of the reading text.

In addition, repetition is also an example of cognitive strategy that is common among both groups of respondents. Repetition strategy enables the students to comprehend the content of the text. Low proficiency students may encounter words that are unknown to them. Therefore, when students repeat the passage, the words that are unknown to them will be known by them. This indirectly shows that they can pay more attention on the content of the text rather than face challenges with unknown words. In an article from, Culver and Morse (2008) highlighted in their article in The Teaching Professor that even students at tertiary level are required to read the text given repeatedly to fully comprehend the information. This shows that students at different levels are encouraged to reread the text to comprehend it.

Additionally, the significant difference of cognitive strategies employed by high and low proficiency is based on the types of cognitive strategies used. Majority of the low proficiency students 
employ only skimming, repetition and translation strategy whereas the high proficiency students employ more than these three cognitive strategies. They include prediction, summarizing, elaboration and guessing. The researcher believes that the high proficiency students are proficient readers because they employ all these strategies. Therefore, teachers should encourage the low proficiency students to employ these cognitive strategies in order to be proficient readers.

\subsection{DISCUSSION}

\section{A. Predominant Cognitive Reading Strategies}

Both low and high proficiency students equally agree that they employ skimming, repetition and translation strategy. These strategies can be considered as the popular strategies among the students.

The first strategy that is discussed in this section is skimming strategy. There are three different stage that skimming is frequently employed. The three stages are pre-reading, reviewing and reading. In the first stage, which is pre-reading, skimming is used to get a clearer picture of the content of the text. Next, during reviewing stage, skimming is suitable to revise the text that has been read. Finally, during the reading stage, skimming is used to briefly read the text given.

Furthermore, previous researchers agree that skimming strategy offers to help students read in more focused and efficient way. This is revealed in a research conducted by Tamsi et al. (2013). According to the questionnaire that has been answered by the students, it is evident that the students' response toward skimming strategy was good. Therefore, it can be concluded that the teacher needs to study more about this strategy in order to introduce it to the students and allow them to successfully read the text given. .

The next strategy discussed in this section is repetition. In this research, repetition involves students rereading the text to understand the content of the text. Previous researchers strongly agree that rereading helps students comprehend the text read (Roskos \& Newman, 2014 cited by Walsh, 2014). This shows that when students read the text more than once, the content of the text can be grasped easily. In addition, rereading aids students read with greater fluency (Pikulski \& Chard, 2005). This certainly allows them to give more consideration to make sense of what they have read. Besides that, rereading helps students to be more precise while reading. As for an example, difficult words to interpret on a first reading become progressively easier to be analyzed.

With so many researches to support it, it is believed that repetition is a strategy employed by majority of students. Teachers should continuously encourage students to employ this strategy. One of the instructional domains where repeated readings can be used is close reading (Walsh, 2014). Close reading can and should be used carefully. It is a method that allows students to reread by focusing on fluency and comprehension.

The third strategy that is discussed in this section is translation. It is the substitution of a text in one language by a text that is alike in another language (Bell, 1991). It is believed that it is essential to understand the concept of translation to get an overview of the process of translation. Jiraphatralikhit et al. (2005) quoted some concepts as follows: 
i. Translation is thoroughly linked to the reading process (Bensoussan, 1990)

ii. Translation is a process which involves the agreement of meaning between writers and readers of the text (Hatim and Mason, 1990)

iii. Translation is the skill of comprehending the text and interpreting it in the target language (Kelly, 2005)

All these definitions of translation imply that students that employ translation strategy can comprehend the text better. They translate the text to first language by maintaining the content and meaning of the text. They can translate using a more general word and also omit words that are not necessary to be mentioned. To sum up, the three cognitive strategies that are predominant among high and low proficiency students are skimming, repetition and translation. These three strategies aid students to understand the reading comprehension texts.

\section{B. Significant Differences In Reading Strategies Employed By High And Low Proficiency Students}

For the significant differences in cognitive reading strategy use, a number of significant points developed from the data. First, data from the questionnaire, triangulated with students' interview and teacher's observation, indicated that the low proficiency students seemed to overlook five cognitive reading strategies. These five cognitive strategies are prediction, analyzing, inferring, summarizing and elaboration strategy. This might be because the low proficiency students are not familiar with these cognitive reading strategies.

The information about the strategy, the steps to employ it and the benefits of it influence the usage of the strategy among the students (Chinn, 2006). One of the reasons why students do not use an appropriate strategy is that they are not exposed to it. The second reason is that they disbelieve the strategy is beneficial. The student who is required to distinguish main and supporting ideas in the text may not believe it will really improve learning, All these show that teachers should play an essential role in teaching appropriate cognitive reading strategies to the low proficiency students.

To sum up, it is clear that low and high proficiency students exhibited different levels of cognitive awareness. The number of cognitive reading strategies used by the high proficiency to enhance their reading skills is higher than the low proficiency students. They are alert when they should employ a particular strategy and when to change to another to facilitate reading comprehension.

\section{Suggested Cognitive Reading Strategies For Low Proficiency Students}

The findings of this research reveal that four cognitive reading strategies are deemed appropriate for the low proficiency students to utilize. The suggested cognitive reading strategies are guessing, elaboration, summarizing and prediction. It is strongly believed that if the low proficiency students employ these four strategies, they will be able to become proficient readers.

The first strategy that is suggested is guessing. Gorjian et al. (2000) investigated the effects of guessing strategy and reveal that contextual guessing improves students' reading comprehension 
skills. Moreover, guessing strategy also enhances students' understanding on vocabulary. Bakhtiarvand (2008) stated that guessing strategy enhanced students' vocabulary skills. This shows that students that employ this strategy are able to speculate the definitions of unknown words in texts and comprehend the text efficiently.

Furthermore, Samiyan and Khorasani (2014) reported on the benefits of guessing strategy towards the learning of vocabulary which indirectly leads to effective comprehension of the reading text. The findings indicate that the respondents, who were taught to use this strategy managed to acquire new words. Therefore, it can be inferred that students who use this strategy will be able to understand the text effectively and efficiently.

The next strategy is elaboration. Elaboration strategy is used to tap the students' prior knowledge about the world and to develop their critical thinking and logical reasoning. According to Irwin (2006) elaborations that incorporate new ideas with past experiences clearly affect and improve recall and increase enjoyment. The effective interaction between linguistic knowledge and knowledge of the world enables the students to be proficient readers. Therefore, low proficiency students should focus in elaborating the details stated in the texts into the real life situations. A recent research highlighted that elaboration strategy facilitates students' reading comprehension in expository texts (Setiasih, 2015). This clearly shows that low proficiency students should be exposed to this strategy in order to be a better reader.

The following strategy is summarizing. It allows students to distinguish the main ideas and supporting details in a text and incorporate the ideas and details in a systematic way. Students' memory improves when they are taught how to summarize. To add on, students learn how to reread, verify, and activate background knowledge Previous researchers suggested that summarizing strategy helps students form relations among notions contained in a text as well as link these notions to background knowledge. Some studies concluded that summarization can aid students to focus on essence of information and therefore develop comprehension (Pearson \& Fielding, 1996).

Paksadian and Rasekh (2012) reported in their study that summarization strategy created a positive effect in the respondents' level of comprehending reading comprehension texts. Similarly, in another study conducted by Khoshsima and Tiyar (2014), the findings also indicated that summarizing strategy enhances the reading comprehension skills of the students. All these clearly show that if low proficiency students employ this strategy, they will be able to improve their level of comprehension.

Jones (2007) proposed three simple steps to enhance summarizing strategy among low proficiency students. The steps are as below:

1. Students read the text.

2. Next, teacher asks students questions based on the text.

3. Finally, teacher instructs students to detect the central ideas in the text

(Jones, 2007)

As a whole, it can be inferred that summarizing strategy aids students to identify main ideas and supporting details. It allows students to concentrate on key words and phrases of the reading 
comprehension text that are worth to be noted. Above all, this strategy enables students to read a large number of texts and highlight the central points to gain a brief understanding of the texts.

The fourth cognitive strategy recommended for the low proficiency students is prediction. High proficiency students seem to continuously and regularly predict what they will be reading before they read the next portion of the text. Their prior knowledge allows them to make predictions. In fundamental nature, they think beforehand by looking forward to approaching words and thoughts by withdrawing what they know about the configuration of the language, about the emphasis of the reading passage, and about the viewpoint of the reading circumstances. Reading for them is making guesses and then verifying the truthfulness of those predictions.

Moreover, Que (2011) indicated that predicting strategy has positive influence on students reading comprehension. In relation to this, teachers need to provide instruction in order to make sure that predicting strategy is used appropriately. As a whole, it is suggested that as students move toward independent integration of the strategy, teachers should provide chances for them to make, revise, and verify their own predictions during pre-reading, while-reading and post-reading stage.

\section{Overview of Research Findings}

Table 3.0 Summary of Research Findings

\begin{tabular}{|c|c|}
\hline Research Objectives & Research Findings \\
\hline \multirow{4}{*}{$\begin{array}{l}\text { Research Objective } 1 \text { - To identify the reading } \\
\text { strategies employed by the Form Three low } \\
\text { proficiency students }\end{array}$} & Skimming \\
\hline & Repetition \\
\hline & Translation \\
\hline & Note-taking \\
\hline \multirow{10}{*}{$\begin{array}{l}\text { Research Objective } 2 \text { - To identify the reading } \\
\text { strategies employed by the Form Three high } \\
\text { proficiency students }\end{array}$} & Skimming \\
\hline & Prediction \\
\hline & Analysing \\
\hline & Inferring \\
\hline & Translation \\
\hline & Summarising \\
\hline & Elaboration \\
\hline & Repetition \\
\hline & Guessing \\
\hline & Note-taking \\
\hline $\begin{array}{l}\text { Research Objective } 3-\text { To find out the } \\
\text { significant differences in reading strategies } \\
\text { employed by the Form } 3 \text { low and high } \\
\text { proficiency students }\end{array}$ & $\begin{array}{l}\text { The significant difference - the number of strategies } \\
\text { employed by them. The suggested cognitive reading } \\
\text { strategies are: } \\
\text { - guessing } \\
\text { - } \quad \text { elaboration } \\
\text { - } \quad \text { summarizing } \\
\text { - } \quad \text { prediction }\end{array}$ \\
\hline
\end{tabular}




\subsection{CONCLUSION}

In conclusion, this research was successfully carried out and it obtained effective results. It is believed that the findings of this research strengthen and enhance the theories on cognitive strategies that are available. To add on, this research revealed a clear picture to the teachers and students, especially the low proficiency students, regarding the usage of cognitive reading strategies. The most common cognitive strategies used by students from both groups are skimming and translation. In addition, the most major difference in reading strategies between both groups of students is that the low proficiency students employ fewer cognitive strategies than high proficiency students. Moreover, other substantial difference includes the types of the cognitive strategies that are employed by both groups of students. Above all, in this research, there are various reading strategies suggested for the low proficiency students. It is believed that if the low proficiency students employ all the suggested cognitive reading strategies, they might be able to become proficient readers.

\section{ACKNOWLEDGMENT}

The study has been made possible with the support from teachers and students of SMK Pasir Putih, Pasir Gudang, Johor.

\section{REFERENCES}

Askari, H. 2013. Contextual Guessing Strategy. Germany: Lambert Academic Publishing

Austin Community College. 2000. Taking Effective Notes. Retrieved from http://sites.austincc.edu/student-skills-workshops/taking-effective-notes/.

Aziz, N. A., Rahim, S. A., Harun, E. H., Adzmi, N. A., Ahmat, H., Bidin, S. and Shaharudin, M. R. 2011. The Reading Strategies Awareness among English as a Second Language (ESL) Learners in Malaysia's University. Theory and Practice in Language Studies. 1(7).

Bakhtiarvand, M. 2008. The Effect of Contextual Guessing Strategy on Vocabulary Recognition in Reading Comprehension texts of Iranian EFL Junior High School students. Retrieved from https:/www.researchgate.net/publication/234154921_The_Effect_of_Contextual_Guessing_St rategyOn_Vocabulary_Recognition_in_ReadingComprehension_texts_of_Iranian_EFLJunior _High_school_students.

Brown, D. H. 1994. Teaching by Principles. New Jersey: Prentice Hall Regents.

Brown, D. L. and Briggs, L. D. 1989. Success in Reading: Four Characteristics of Strategic Readers. Retrieved from

http://scholarworks.wmich.edu/cgi/viewcontent.cgi?article=1650\&context=reading_horizons

Brown, R., Pressley, M., Van Meter, P., \& Schuder, T. 1996. A Quasi-experimental Validation of Transactional Strategies Instruction with Low-achieving Second-grade Readers. Journal of Educational Psychology. 88: 18-37.

Cameron, S. 2009. Teaching Reading Comprehension Strategies: A Practical Classroom Guide. Pearson: 
North Shore New Zealand.

Carrell, P. L., \& Grabe, W. 2002. Reading. In N. Schmitt (Ed.). An Introduction to Applied Linguistics. London: Arnold. 233-250.

Chan, C. K. K., Burtis, J., Scardamalia, M., \& Bereiter, C. 1992. Constructive Activity in Learning from Text. American Educational Research Journal. 29: 97-118.

Chi, M. T. H., Bassok, M., Lewis, M. W., Reimann, P., \& Glaser, R. 1989. Self-explanations: How Students Study and Use Examples in Learning to Solve Problems. Cognitive Science. 13: 145182.

Chinn, C. A. 2006. Learning to Argue. In A. M. O'Donnell, C. Hmelo-Silver, \& G. Erkens (Eds.). Collaborative Learning, Reasoning, and Technology Mahwah, NJ: Erlbaum. 355-383.

Culver, T. F. \& Morse, L. W. 2008. The Teaching Professor. Retrieved from https://www.canadacollege.edu/inside/CIETL/getting_students_to_read.pdf.

Duke, N. K. \& Pearson, P. D. 2002. Effective Practices for Developing Reading Comprehension. In A. E. Farstrup \& S. J. Samuels (Eds.). What Research Has to Say About Reading Instruction. Third Edition. Newark, DE: International Reading Association. 205-242.

Gorjian, B., Hayati, A., and Sheykhiani, M. J. 2000. The Role of Gisting and Contextual Guessing Reading Strategies in Learners' Performance in Multiple-choice Cloze Tests of Reading Comprehension. Retrived from

http://www.ukm.my/solls09/Proceeding/PDF/Bahman,\%20hayati\%20et\%20al.pdf.

Graham, S., MacArthur, C., \& Schwartz, S. 1995. Effects of Goal Setting and Procedural Facilitation on the Revising Behaviors and Writing Performance of Students with Writing and Learning Problems. Journal of Educational Psychology. 87: 230-240.

Gunning, T. G. 1996. Creating Reading Instruction for All Children. Chapter 6, 192-236.

Guthrie, J. T., Wigfield, A., Barbosa, P., Perencevich, K. C., Taboada, A., Davis, M. H., et al. 2004. Increasing Reading Comprehension and Engagement through Concept-oriented Reading Instruction. Journal of Educational Psychology. 96: 403-423.

Halim, A. and Mohamed, M. 2006. Knowledge of Linguistic Cues among Malay EFL Students and Teachers' Practices in the Teaching of Reading Skills. Malaysian Journal of ELT Research. $7(2)$

Irwin, J. W. 2006. Teaching Reading Comprehension Processes. New Jersey: Prentice-Hall, Inc.

Jiraphatralikhit, J., Klinpoon, S., \& Kaewjan, S. 2005. An Analysis of Strategies in Translation of the Movie Subtitle: Behind the Painting. Research Gate. 1: 54-71.

Jones, R. 2007. Strategies for Reading Comprehension: Summarizing. Retrieved from http://www.readingquest.org/strat/summarize.html.

Julius, A. T. 2015. Appraisal of Seven Critical Reading Strategies Employed by Teachers in Ogun State Senior Secondary Schools to Teach Reading Comprehension. African Journal for Psychological and Social Sciences Issues. 18(1).

Karami, H. 2008. Reading Strategies: What Are They? Retrieved from http://files.eric.ed.gov/fulltext/ED502937.pdf.

Khoshsima, H. and Tiyar, F. R. 2014. The Effect of Summarizing Strategy on Reading Comprehension of Iranian Intermediate EFL Learners. International Journal of Language and 
Linguistics. 2(3): 134-139.

King, K. 2008. Reading Strategies. Retrieved from http:/www.isu.edu/ kingkath/readstrt.html.

Koda, K. 2007. Reading and Language Learning: Crosslinguistic Constraints on Second Language Reading Development. Language Learning. 57(1): 1-44.

Kojima, H. and Narita, H. 2004. The Effects of Word Guessing Strategy Instruction on Reading Comprehension. Retrieved from http:/repository.ul.hirosakiu.ac.jp/dspace/html/10129/539/AN00211590_91_75.pdf.

Kucukoglu, H. 2013. Improving Reading Skills through Effective Reading Strategies. Procedia-Social and Behavioral Sciences. 70.

Liao, P. S. 2006. EFL Learners Beliefs About Strategy Use of Translation in English Learning. RELC Journal. 37(2): 191-215.

Longman, D. and Atkinson, R. 1999. College Learning and Study Skills. Wadsworth/Thomson Learning.

Marzano, R. 2010. Teaching Inference. Educational Leadership. 67(7): 80-01. Retrived from http://www.ascd.org/publications/educational-leadership/apr10/vol67/num07/TeachingInference.aspx.

Mohamed, A. R., Chew, J. \& Kabilan, M. K. 2006. Metacognitive Reading Strategies of Good Malaysian Chinese Learners. Universiti Sains Malaysia. Malaysian Journal of ELT Research. MELTA.

Nietfeld, J. L. and Shraw, G. 2002. The Effect of Knowledge and Strategy Explanation on Monitoring Accuracy. Journal of Educational Research. 95.

Nordin, N. M., Rashid, S. M., Zubir, S. I. S. and Sadjirin, R. 2013. Differences in Reading Strategies: How ESL Learners Really Read. Procedia-Social and Behavioral Sciences. 90.

O’Malley, J. M. and Chamot, A. U. 1990. Learning Strategies in Second Language Acquisition. London: Cambridge University Press

Oxford, R. 1990. Language Learning Strategies: What Every Teacher Should Know. New York: Newbury House Publishers.

Pakzadian, M. and Rasekh, A. E. 2012. The Effects of Using Summarization Strategies on Iranian EFL Learners' Reading Comprehension. English Linguistics Research. 1(1).

Pani, S. 2004. Reading Strategy Instruction through Mental Modeling. ELT Journal. 58: 355-362.

Pearson, P. D., \& Fielding, L. 1996. Comprehension Instruction. In R.Barr, M. L. Kamil, P. Mosenthal,\& P. D. Pearson (Eds.). Handbook of Reading Research. 2: 815-860. White Plains, NY: Longman.

Pikulski, J. J., \& Chard, D. J. 2005. Fluency: Bridge between Decoding and Reading Comprehension. Reading Teacher. 58: 510-519.

Prichard, C. 2014. Reading Strategy Use of Low- and High-Proficiency Learners and the Effect of Reading Instruction. Retrieved from http://ousar.lib.okayamau.ac.jp/file/53178/bhe_010_115_122.pdf.

Que, H. T. K. 2011. Improving Students' Reading Comprehension through Predicting Strategy Instruction: An Action Research at Cao Ba Quat Upper Secondary school. Retrieved from http://repositories.vnu.edu.vn/jspui/bitstream/123456789/38700/1/Microsoft\%20Word\%20$\% 20$ Tom\%20tat\%20luan\%20van.pdf. 
Raj, A. S. 2008. The Effectiveness of the Question and Answer Relationship (QAR) Strategy in Enhancing Reading Comprehension among ESL Students. Faculty of Education and Languages: Open University Malaysia.

Rea, D. M. \& Mercuri, S. P. 2006. Research-based Strategies for English Language Learners. Portsmouth, NH: Heinemann.

Richards, J. C., Platt, J. and Platt, H. 1992. Longman Dictionary of Language Teaching and Applied Linguistics. Foreign Language Teaching and Research Press. London: Longman. Beijing.

Richek, M. A, Caldwell, J. A., Jennings, J. H. \& Lerner, J. W. 2002. Reading Problems-Assessment and Teaching Strategies. Boston, Massachusetts: Pearson Education Company.

Row, B. \& Smith, S. 2005. Teaching Reading in Today's Middle Schools. Boston: Houghton Mifflin.

Samiyan, L. V. \& Khorasani, S. R. 2014. The Comparison between Contextual Guessing Strategies vs. Memorizing a List of Isolated Words in Vocabulary Learning Regarding Long Term Memory. International Journal of Science Culture and Sport. 3(1): 12-18. Retrieved from http://www.iscsjournal.com/Makaleler/933207334_3.sayi_ic-sayfalar_2leyla.pdf.

Semtin, S. A. and Maniam, M. 2015. Reading Strategies among ESL Malaysian Secondary School Students. International Journal of Evaluation and Research in Education. 4(2).

Setiasih, L. 2015. Chunking, Elaborating and Mapping Strategies in Teaching Reading Comprehension Using Content Area Materials. World Journal of English Language. 5(1): 32-47.

Retrieved

from

https://www.researchgate.net/publication/273487085_Chunking_Elaborating_and_Mapping_S

trategies_in_Teaching_Reading_Comprehension_Using_Content_Area_Materials.

Stuck, A. 2000. Setting a Purpose. Retrieved from http://www.ohiorc.org/adlit/strategy/strategy_each.aspx?id=1.

Tamsi, R. K., Zuhri, F. and Kurniasih, E. 2013. The Implementation of Skimming and Scanning Strategies in Teaching Reading Narrative Text to the Tenth Grade Students of SMAN 21 SURABAYA. Retrived from http://ejournal.unesa.ac.id/index.php/retain/article/view/2618/4577.

Vacca, R. T. and Vacca, J. L. 1999. Content Area Reading: Literacy and Learning Across the Curriculum. New York:Longman.

Walsh, R. 2014. The Power of Rereading. Retrieved from http://russonreading.blogspot.my/2014/12/the-power-of-rereading.html.

Zwiers, J. 2005. Building Reading Comprehension Habits in Grades 6-12. Newark, DE: International Reading Association. 